\title{
Indecent Exposure: Do Warrantless Searches of a Student's Cell Phone Violate the Fourth Amendment?
}

\author{
Amy Vorenberg
}

\section{INTRODUCTION}

Alex D. ${ }^{1}$ was bored and drifting as he sat in his English Literature class one gray winter day. Looking to amuse himself, he did what many teens do. He looked down at his cell phone to check for messages. Alex knew he was violating a school rule that prohibited cell phone use during class, but he figured he could get away with it. His teacher, however, noticed Alex's downward glances and recognized the telltale sign of probable cell phone use. She promptly confronted him and confiscated the phone.

The teacher was enforcing what has become a common policy in many schools. ${ }^{2}$ When class was over, she took the phone to the main office where it would be held until the end of the day.

On this particular day, however, things progressed a little differently. The school principal took possession of the phone after it was brought into the office. Acting upon general rumors of drug dealing in the school, she opened Alex's phone and started reading the stored text messages. She found a very recent text message from "Brian" that

\footnotetext{
* Professor of Law, University of New Hampshire School of Law. The author wishes to thank Professors Kimberly Kirkland, Dana Remus, John Greabe, Chris Johnson, Risa Evans, and Richard Albert for their ideas and feedback. In addition, the author extends her appreciation to Research Assistants Lauren Breda, Nathan Warecki and Caroline Schleh for the many hours of work they provided. The author thanks Roger Wellington for his editing contributions, and Honorable Paul Barbadoro and Attorney David Rothstein for their advice and feedback Finally, the author is grateful to "Brian"-now a successful college student-who was willing to share his personal experience.

${ }^{1}$ These facts are based on a true story.

2 Virginia Groark, Tired of Interruptions, Schools Ban Cell Phones, N.Y. Times, Sept. 9, 2001, at 14CN; Paul Lieberman, Parents Answer Cell Phone Ban in N.Y. Schools, L.A. Times, May 29, 2006, at A4; Region in Brief, Cell Phones Now Banned in Hub's Schools, Bos. HerAlD, Mar. 24, 2005, News at 33.
} 
read: "Yo, need a bag?"3 The principal, pretending to be Alex, responded to the text: "yea I can wait at back door ... I will hide out in a room and look for u."

Brian replied quickly and the principal, posing as Alex, began a lengthy text conversation that culminated in an agreement to meet in a nearby parking lot so "Alex" could purchase a bag of marijuana." Unaware of the ruse, Brian showed up at the parking lot, where he was arrested by the police with the principal looking on.

The principal reported to the police that she routinely scrolled through students' confiscated phones and placed calls to numbers in the contact list in an attempt to catch students using their phones in school. ${ }^{5}$ Although perhaps not as proactively as the principal of Alex's school, administrators are playing out similar scenarios all around the country. ${ }^{6}$ Given the potential for disruption and distraction, it is clearly reasonable to enjoin student use of cell phones during instructional periods. Confiscation of a cell phone is a logical consequence for violating the rule. However, what school officials can lawfully do with a phone after confiscation is not clear.

Over seventy-five percent of teenagers carry a cell phone on a daily basis, and many use the device as a private diary and portal for personal data and information. ${ }^{7}$ When the principal opened Alex's phone and began searching through his texts and information, she could have stumbled upon a variety of personal information and images including appointments with therapists or doctors, personal messages related to

${ }^{3}$ Clare Trapasso, Teen Sues After Principal Lures Him into Alleged Drug Deal, UNION LEADER, Apr. 18, 2008, at A6.

4 The case discussed here took place at a private school where administrators are unconstrained by the Fourth Amendment. However, this type of scenario is routinely played out in public schools.

${ }^{5}$ Police report - on file with author.

${ }^{6}$ High School Not Confidential: When Officials Search Student Cell Phones, CHICAGO TRIBUNE, Feb. 5, 2012, available at http://articles.chicagotribune.com/2012-0205/news/ct-edit-stevenson-20120205_1_school-searches-strip-search-stevenson-student; Marc Freeman, Student Rights Group Targets Boca High Cellphone Searches, Sun Sentinel, July 26, 2011, available at http://articles.sun-sentinel.com/2011-0726/specialsection/fl-boca-high-cell-phone-complaint-20110725_1_student-cellphonesstudent-phones-high-school-student-handbook; Rick Rojas, School Phone Policies Assessed, L.A. TimES, Nov. 12, 2011, available at http://articles.latimes.com/2011/nov/ 12/local/la-me-cellphones-20111112; J.W. v. DeSoto County Sch. Dist., 2:09-CV00155-MPM, 2010 WL 4394059 (N.D. Miss. Nov. 1, 2010).

7 Amanda Lenhart et al., More and More Teens on Cell Phones, PeW InTERnet And AMERICAN LifE PROJECT, Aug. 19, 2009, available at http://pewresearch.org/pubs/ 1315/teens-use-of-cell-phones. 
private family or medical issues, or embarrassing text messages with friends that have nothing to do with criminal activity. The cell phonepractically an appendage of most teenagers these days-is an extension of a teenager's life and its contents reflect a great deal about them. ${ }^{8}$

Teens appear willing to capture in their phone's text or photos their most private world. The ease with which that information can be uploaded to the internet (typically Facebook) might create an assumption that teens do not care about maintaining their privacy. However, the opposite is true. Teenagers are willing to share private information with their peers in text messages and place private data on their phones precisely because they expect them to remain private, or at least confined to a known world of friends and other contacts.' When school administrators look at a student's texts or other cell phone information, they open a door into the student's private life.

In this article, I argue that school administrator searches of a student's cell phone should require a warrant, unless there are urgent circumstances involving safety. Students who attend a public school come within the privacy protections of the Fourth Amendment. ${ }^{10}$ How far those protections should go necessitates examining a student's subjective view of what is private given their "adolescent vulnerability." 11 In Safford v. Redding, the U.S. Supreme Court held a strip search of a student unlawful, in part because school childrens' unique subjective view of their own privacy should be afforded special consideration. This same unique perspective should be applied to the contents of a student's cell phone. Because "tweens" and teenagers in particular place so much private information on their phones, their expectation of privacy in their phones should be accorded substantial protection.

Given that the vast majority of children in the United States attend public school (about ninety percent), most school administrators are bound by constitutional rules. Absent urgent safety concerns, school policies that allow warrantless searches of cell phones violate the Fourth Amendment privacy interests of students. After all, cell phones in and of themselves are not dangerous. They cannot hold drugs or weapons-

8 Amanda Lenhart et al., Teens and Mobile Phones: Text Messaging Explodes as Teens Embrace It as the Centerpiece of Their Communication Strategies with Friends, PEW INTERNET, Apr. 20, 2010, available at http://pewinternet.org/ /media//Files/ Reports/2010/PIP-Teens-and-Mobile-2010-with-topline.pdf.

${ }^{9}$ Mary Graw Leary, Reasonable Expectation of Privacy for Youth in a Digital Age, 80 Miss. L. J. 1033, 1043 (2011).

${ }^{10}$ New Jersey v. T.L.O., 469 U.S. 325, 333 (1985).

${ }^{11}$ Safford Unified Sch. Dist. No.1 v. Redding, 129 S. Ct. 2633, 2641 (2009). 
only information about drugs or weapons. Given that a cell phone contains highly private information, poses no imminent danger, and its contents can be preserved while a warrant is obtained, school officials should be required to get a warrant unless there are exigent circumstances such as an immediate, apparent threat to student safety.

In the first part of this article, I explain the governing law on school searches and examine how a student's expectation of privacy should be measured. Second, I explain the reasoning for requiring a warrant to search a student's cell phone. Finally, I suggest guidelines for cell phone searches in school.

\section{Fourth Amendment Rights In THE SCHOOL CONTEXT}

Although students may carry a backpack to school loaded with books, notebooks, and other items, many will deposit these belongings in their lockers. However, there is one item most students will keep with them at all times-their cell phone. It is hard to overestimate the importance of the cell phone in modern teen culture. It has become the essential communication device and is consulted with mind-numbing frequency. ${ }^{12}$

Like their adult counterparts, students are protected from unreasonable searches, and thus, assuming that the school official's conduct is a "search," any Fourth Amendment inquiry turns on whether a search is reasonable or unreasonable. ${ }^{13}$ Unlike adults however, students in school enjoy less protection of their privacy because a student's right to privacy in his or her belongings has been deemed secondary to concerns for students' overall safety and well-being. Schools act in place of a parent-or, "in loco parentis." Thus, "reasonableness" has a distinct definition for students in a school setting. Before a school official can search a student, the justification for the search must be "reasonable at its inception" and "reasonable in scope." 14 Most courts will give school officials wide latitude in what is "reasonable," given the realities of keeping schools safe. School administrators can search lockers, backpacks, pocketbooks, and other items of personal property with only a moderate degree of suspicion-something more than a hunch, but less than what would be required to meet a "preponderance of evidence" standard. ${ }^{15}$

${ }^{12}$ Lenhart, supra note 8 , at 82-84.

13 T.L.O., 469 U.S. at 341.

${ }^{14} \mathrm{Id}$. at $341-42$

15 Redding, 129 S. Ct. at 2647; Commonwealth v. Cass, 709 A.2d 350, 357 (Pa. 1998) (expectation of privacy in locker is minimal). 
The more intrusive the search, the more suspicion needed-and thus searches fall along a spectrum of intrusiveness. ${ }^{16}$ Searches of lockers and backpacks fall close to one end of the spectrum because the level of intrusion on the student is low and thus less suspicion is needed. ${ }^{17}$ Strip searches fall on the opposite end of the spectrum and require the greatest degree of suspicion. Because searching a student's body places the student in an embarrassing and exposed position, administrators must have individualized suspicion of the student's wrongdoing and an indication of potential danger posed by the object of the search. ${ }^{18}$

In New Jersey v. T.L.O., respondent, a fourteen-year-old high school freshman, was caught smoking in the bathroom along with her classmate in violation of school policy. ${ }^{19}$ When brought before the principal, the classmate admitted her infraction but T.L.O. maintained her innocence and said she did not smoke cigarettes. ${ }^{20}$ The principal demanded to see T.L.O.'s purse, opened the purse, and found a pack of cigarettes. $^{21}$ As he retrieved the cigarettes, the principal noticed some rolling papers. ${ }^{22}$ Aware that students who smoke marijuana customarily use rolling papers, the principal suspected that searching further would reveal evidence of drug use. ${ }^{23}$ Indeed, a thorough search of the purse revealed some marijuana. ${ }^{24}$

Having found the drugs, the principal went further and opened a zippered compartment of the purse where he found an index card with names on it and some letters. Upon examination, the letters revealed information that suggested the respondent was involved in drug dealing. ${ }^{25}$ After being turned over to the police, the respondent confessed to drug dealing and was subsequently charged as a juvenile. The charges were based on the evidence found by the principal and the respondent's confession. ${ }^{26}$ T.L.O. claimed that she had been unlawfully searched and

${ }^{16}$ Redding, 129 S. Ct. at 2643.

${ }^{17}$ See T.L.O., 469 U.S. at 342 ("[A] search will be permissible in its scope when the measures adopted are reasonably related to the objectives of the search and not excessively intrusive in light of the age and sex of the student and the nature of the infraction.").

18 See Redding, 129 S. Ct. at 2643.

19 T.L.O., 469 U.S. at 328.

${ }^{20} \mathrm{Id}$.

${ }^{21} I d$.

${ }^{22} I d$.

${ }^{23} \mathrm{Id}$.

${ }^{24} \mathrm{Id}$.

${ }^{25}$ New Jersey v. T.L.O., 469 U.S. 325, 328 (1985).

${ }^{26} \mathrm{Id}$. at 329. 
her confession was thus tainted by the bad search; consequently, the respondent moved to suppress the evidence and her confession. ${ }^{27}$

Though holding that the Fourth Amendment applies in a public school setting, the Court concluded that the principal's actions had not violated T.L.O.'s Fourth Amendment rights. ${ }^{28}$ The principal's search of T.L.O.'s purse was reasonable because he had received a report of her smoking in the lavatory and her denials provided a sufficient basis to examine the contents of her purse. ${ }^{29}$ The discovery of the rolling papers, the Court held, gave rise to further suspicion that the girl was a dealer and justified the principal opening and reading the letters that showed T.L.O.'s involvement in drug dealing. ${ }^{30}$ The rolling papers gave the principal reasonable, individualized suspicion to look further into the purse and the search was thus reasonable under the circumstances. ${ }^{31}$

The T.L.O. opinion was consistent with the Court's move away from a strict in loco parentis justification in school cases involving student's constitutional rights. Before T.L.O., the Court had acknowledged that the compulsory nature of a publicly mandated education diminishes the concept of in loco parentis and therefore students have First Amendment rights and school officials are subject to the Due Process Clause of the Fourteenth Amendment. ${ }^{32}$ In T.L.O., the Court fashioned a balancing

${ }^{27} \mathrm{Id}$.

${ }^{28}$ Id. at $332-33$.

${ }^{29} \mathrm{Id}$. at 345.

${ }^{30} \mathrm{Id}$. at 347.

${ }^{31}$ New Jersey v. T.L.O., 469 U.S. 325, 347 (1985).

32 Goss v. Lopez, 419 U.S. 565 (1975) (student's right to due process under the Fourteenth Amendment); Tinker v. Des Moines Indep. Cmty. Sch. Dist., 393 U.S. 503 (1969) (student's right to free speech under the First Amendment). Arguably, the in loco parentis characterization is skewed. School administrators' concern for a child's welfare lacks the basic nurturing and protective instinct that a parent's concern has, and instead carries with it the more authoritarian role of guardian. See William Buss, The Fourth Amendment and Searches in Public Schools, 59 IOWA L. REV. 739, 768 (1974): "One of the things that makes in loco parentis such an erroneous phrase in this context is precisely the absence of a genuinely parental protective concern for the student who is threatened with the school's power. It is presumably a characteristic of the use of parental force against a child that the force is tempered by understanding and love based on a close, intimate, and permanent child-parent relationship. What so many of the courts persist in talking about as a parental relationship between school and student is really a law enforcement relationship in which the general student society is protected from the harms of anti-social conduct." Moreover, the compulsory nature of school attendance further undermines the in loco parentis characterization. See Anne Proffitt Dupree, Should Students Have Constitutional Rights? Keeping Order in the Public Schools, 65 GEO. WASH. L. REV. 49, 72 (1996):"Commentators and Courts alike have criticized 
test based on a threshold of reasonableness-not unlike Fourth Amendment analysis outside the school context. ${ }^{33}$ The search, the Court held, must be conducted in a reasonable manner insofar as the measures applied reasonably relate to the objectives of the search and are not overly intrusive in light of the student's circumstances. ${ }^{34}$ School searches must therefore meet a two-part test. First, the search must be justified at its inception. ${ }^{35}$ Second, the search must reasonably relate in scope to the circumstances that justified the search in the first place. ${ }^{36}$ The T.L.O. two-part test requires balancing the type of item searched, the nature of the infraction, and the quality of the suspicion. ${ }^{37} \mathrm{~A}$ deficiency in one of these can be made up by the heightened quality of another. Courts, including the Supreme Court, have been using the T.L.O. test with varying degrees of consistency ever since the case was decided. ${ }^{38}$

While T.L.O. was a case in which individualized suspicion of a particular student justified the search, there are a number of cases where the search was premised on general concerns. ${ }^{39}$ School-wide searches of lockers and backpacks are increasingly routine in public schools, as is random drug testing. ${ }^{40}$ These searches are not targeted at any one

the concept of parental delegation of authority in a system of compulsory education in which neither parent nor child has any choice in whether to attend school. The criticism focused on the source of the school power: 'Under a system of compulsory education, a school authority is the agent of the governmental branch charged with carrying out the law." (internal citation omitted).

The U.S. Supreme Court, as early as 1966, acknowledged that the parens patriae theory was not serving its purpose. Referring to Washington, D.C.'s juvenile court system, Justice Fortas wrote: "There is much evidence that some juvenile courts, including that of the District of Columbia, lack the personnel, facilities and techniques to perform adequately as representatives of the State in a parens patriae capacity, at least with respect to children charged with law violation. There is evidence, in fact, that there may be grounds for concern that the child receives the worst of both worlds: that he gets neither the protections accorded to adults nor the solicitous care and regenerative treatment postulated for children.” Kent v. U.S., 383 U.S. 541, 556 (1966).

33 T.L.O., 469 U.S. at 335, 337.

${ }^{34} I d$. at 342 .

35 Id. at 341 .

${ }^{36} \mathrm{Id}$.

37 See id. at 345-47.

${ }^{38}$ Safford Unified Sch. Dist. No.1 v. Redding, 129 S. Ct. 2633, 2643-44 (2009).

${ }^{39}$ Bd. of Educ. of Indep. Sch. Dist. No. 92 of Pottawatomie Cnty. v. Earls, 536 U.S. 822 (2002); Vernonia Sch. Dist. v. Acton 47J, 515 U.S. 646 (1995).

40 Todd v. Rush Cnty. Sch., 133 F.3d 984 (7th Cir. 1998) (testing students involved in extracurricular activities for drugs); Thompson v. Carthage Sch. Dist., 87 F.3d 979 (8th Cir. 1996) (using metal detector to search for weapons on sixth-through twelfth-grade males); Schaill ex rel. Kross v. Tippecanoe Cnty. Sch. Dist., 864 F.2d 1309 (7th Cir. 
individual, but instead seek to root out contraband by searching all students. Increased drug use, violence, or other unauthorized conduct usually prompts the search. ${ }^{41}$ The Court has issued a broad test to justify general searches. School administrators must have a basis similar to that for a particularized search, but must additionally show the presence of a "compelling governmental interest" in deterring drug use or demonstrate an "interest that appears important enough to justify the particular search at hand, in light of other factors that show the search to be relatively intrusive upon a genuine expectation of privacy." 42

Although this article's focus is on searches of individual students, the rationale for allowing generalized searches bears discussion because that same rationale has justified searches that include random urine testing. Such a search might seem intrusive, but the Supreme Court characterizes it as an insignificant intrusion with respect to a student's privacy. ${ }^{43}$

In 1989, the Supreme Court ruled in favor of suspicionless random drug testing of adults after government employers began to institute random drug testing for workers. ${ }^{44}$ When schools began to institute random drug testing on minors as a safety and prevention program in the mid-nineties, the Supreme Court weighed in on the practice. In Vernonia School District v. Acton, the Supreme Court upheld mandatory random drug testing for student athletes. Noting that the factors permitting a lawful search in T.L.O. were not exactly applicable to

1988) (testing students involved in extracurricular activities for drugs); In re Dengg, 724 N.E.2d 1255 (Ohio Ct. App. 1999) (conducting school-wide search for illicit contraband using drug-sniffing police canines); In re Latasha W., 60 Cal. App. 4th 1524 (1998) (instituting random metal detector searches for weapons on campus); In re F.B., 658 A.2d 1378 (Pa. Super. Ct. 1995) (conducting metal detector scans and bag searches of students for weapons); People v. Dukes, 580 N.Y.S.2d 850 (N.Y. Crim. Ct. 1992) (searching students entering campus for weapons using metal detectors).

${ }^{41}$ See, e.g., Vernonia Sch. Dist., 515 U.S. at 649.

${ }^{42} \mathrm{Id}$. at 661.

43 Although students do not shed their constitutional rights at the schoolhouse gate, "students within the school environment have a lesser expectation of privacy than members of the population generally." Tinker v. Des Moines Indep. Cmty Sch. Dist., 393 U.S. 503, 506 (1969). See also New Jersey v. T.L.O., 469 U.S. 325, 348 (1985).

44 See Nat'l Treasury Employees Union v. Von Raab, 489 U.S. 656, 668 (1989) (holding that suspicionless drug testing for government employees applying for promotion to positions involving interdiction of illegal drugs or requiring them to carry firearms was reasonable, on balance, under Fourth Amendment); see also Skinner v. Ry Labor Executives' Assn., 489 U.S. 602 (1989) (finding suspicionless drug and alcohol testing for Federal Railway Administration employees constitutional under Fourth Amendment). 
circumstances involving a generalized search, the Court allowed for a "reasonableness" standard even in the absence of any individualized suspicion. ${ }^{45}$ In Vernonia School District, the drug testing was prompted by concerns that student athletes were highly involved in the school's drug culture. ${ }^{46}$ The Court articulated a new test loosening the requirement of individualized suspicion where governmental interests outweigh the level of intrusion. The Court set out three factors to consider in applying the balancing test: 1) the nature of the privacy interest upon which the search at issue intrudes; 2) the character of the intrusion; and 3) the nature and immediacy of the governmental concern and the efficacy of the means utilized to address that concern. ${ }^{47}$

In Board of Education of Independent School District v. Earls, the Supreme Court upheld a school board mandate that required all students participating in extracurricular activities to submit to random drug testing. ${ }^{48}$ The method of urine collection was not deemed to be a particularly intrusive exercise because the school monitor waited outside the bathroom stall listening for normal sounds of urination. Further, the results of the tests were used for only limited purposes. ${ }^{49}$ Although in Earls the Court discussed the other prongs of the Vernonia School District three-part test, the compelling governmental interest factor was the most influential in the Court's analysis. ${ }^{50}$ The Court cited statistics relating to drug abuse in schools nationally and gave that data as much weight as the testimony regarding the school's problem (which was described as "not major")..$^{51}$

Whether a search is based on individualized or generalized suspicion, it is always evaluated within the unique context of a student's privacy interests and the school's need to maintain order and discipline, along with a school's responsibility for the safety of its students. ${ }^{52}$ In

\footnotetext{
45 Vernonia Sch. Dist. v. Acton 47J, 515 U.S. 646, 653-53 (1995).

46 Id. at 649.

${ }^{47} \mathrm{Id}$. at 656-60.

${ }^{48}$ Bd. of Educ. of Indep. Sch. Dist. No. 92 of Pottawatomie Cnty. v. Earls, 536 U.S. 822, 826-28 (2002).

${ }^{49}$ Results were not placed in students' files and once they had a positive test, there were still given several chances before they were taken out of the activity. Id. at 832-34.

${ }^{50}$ Id. at $834-36$.

${ }^{51}$ Id. at 843 (Ginsburg, J., dissenting).

52 Safford Unified Sch. Dist. No.1 v. Redding, 129 S. Ct. 2633, 2639 (2009); Earls, 536 U.S. at 830; Vernonia Sch. Dist. v. Acton 47J, 515 U.S. 646, 656 (1995) ("The reasonableness inquiry cannot disregard the schools' custodial and tutelary responsibility for children.").
} 
either case, the degree of suspicion must increase substantially to justify searches that are more personally intrusive.

Returning for a moment to the image of the public school child entering school wearing a coat and carrying her backpack, her zone of expected privacy becomes greater the closer the item is to her body. Thus, a student's privacy interest in her locker is minimal. ${ }^{53}$ To begin with, lockers are school property, and school districts often have policies that specifically state that a student has no privacy interest in his or her locker. ${ }^{54}$ To the extent that lockers are repositories for private items like purses or jackets, courts recognize a student's heightened expectation of privacy concerning those items, as opposed to the locker itself. ${ }^{55}$ Such items are recognized as more private and thus more individualized suspicion is required prior to a search. ${ }^{56}$

Pockets, backpacks, and purses-items that are part of a student's clothing or carried by students-are subject to stiffer guidelines in terms of a search. ${ }^{57}$ Where school administrators have specific information regarding a student's possession or use of drugs or weapons, a search of their pockets, backpacks, or purses is likely permissible. ${ }^{58} \mathrm{On}$ the other hand, an anonymous tip or rumor is likely insufficient for a search of a student's personal belongings or pockets because the information prompting the search lacks the level of particularization that would warrant an intrusion of belongings being worn or carried by the student. ${ }^{59}$ For example, in a Pennsylvania case, a vice principal's search of a student's purse that was based on anonymous tips of her possible possession of a marijuana pipe was held unlawful. ${ }^{60}$

However, even in cases where the source of information is anonymous, if the tip includes information about weapon possession, dangerous drug distribution, or other facts that pose a risk to student and

53 Commonwealth v. Cass, 709 A.2d 350, 357 (Pa. 1998).

${ }^{54}$ State v. Jones, 666 N.W.2d 142, 147 (Iowa 2003); see In re Patrick Y., 746 A.2d 405, 414 (Md. 2000); see also Shoemaker v. State, 971 S.W.2d 178, 182 (Tex. App. 1998); In re Isiah B., 500 N.W.2d 637, 641 (Wis. 1993) (where school policies specifically disclaimed students' privacy right for the contents of their lockers).

55 Jones, 666 N.W.2d at 148.

56 In re Adam, 697 N.E.2d 1100, 1108 (Ohio 1997).

${ }^{57}$ In re J.N.Y., 931 A.2d 685 (Pa. Super. Ct. 2007).

58 See, e.g., State v. Drake, 139 N.H. 662, 667 (1995) (pockets and backpacks); Matter of Gregory M., 627 N.E.2d 500, 582 (N.Y. 1993) (backpacks).

59 In re J.N.Y., 931 A.2d at 688-89; see also Texas v. K.C.B., 141 S.W.3d 303, 309 (2004) (finding that the possible presence of drugs on a student does not warrant searching a student's undergarments when the suspicion is based on an anonymous tip). ${ }^{60}$ In re J.N.Y., 931 A.2d at 689. 
faculty safety, courts are likely to uphold the search. ${ }^{61}$ Despite the increased intrusiveness, the court will tip the balance in favor of the school's interest in promoting and protecting a safe environment for school children. ${ }^{62}$

If a student's lack of expected privacy in a locker is at one end of the spectrum, searches that involve the body are at the opposite end. Searches by school administrators that expose a student's body require a high degree of particularized suspicion. ${ }^{63}$ The one notable exception involves searches of students engaged in athletics or co-curricular activities who are allowed somewhat less privacy than other students. ${ }^{64}$ In Vernonia School District, the Supreme Court upheld the urine testing of student athletes, partly because those students were said to be accustomed to a certain degree of exposure because they "suited up" in the locker room, and followed rules that required physical exams. ${ }^{65}$

Seven year later, in Earls, the Supreme Court seemed to cast aside its "athletes are different" reasoning when it expanded authorization for suspicionless drug testing to all students involved in co-curricular activities. ${ }^{66}$ Claiming that their decision in Vernonia School District did not rely heavily on the fact that athletes are subject to decreased privacy, the Court in Earls found that students involved in any extracurricular activity were subject to communal undress and "off-campus travel" and therefore, their expectation of privacy was limited. ${ }^{67}$ In both Vernonia School District and Earls, the Court found that the level of intrusion (a monitor in a bathroom listening for the sounds of normal urination) was

61 Thomson v. Carthage Sch. Dist., 87 F.3d 979, 983 (8th Cir. 2004) (weapon possession); In re Cody S., 16 Cal. Rptr. 3d 653, 655-56 (Ct. App. 2004) (weapon possession); In re Boykin, 237 N.E.2d 460 (Ill. 1968) (weapon possession).

62 See, e.g., In re Cody S., 16 Cal. Rptr. 3d at 655-56.

${ }^{63}$ Vernonia Sch. Dist. v. Acton 47J, 515 U.S. 646, 658 (1995); see also Phanuef v. Fraikin, 448 F.3d 591, 597 (2d Cir. 2006) (unreasonable strip search of student's under garments for marijuana); Beard v. Whitmore Lake Sch. Dist., 402 F.3d 598, 605 (6th Cir. 2005) (unlawful strip search of male and female students for stolen money); Hedges v. Musco, 204 F.3d 109, 116-17 (3d Cir. 2000) (blood test and urinalysis for suspected drug use); Jenkins ex rel. Hall v. Talladega City Bd. of Educ., 115 F.3d 821, 824 (11th Cir. 1997) (en banc) (strip search for suspected theft); Cornfield ex rel. Lewis v. Consol. High Sch. Dist., 991 F.2d 1316, 1320-21 (7th Cir. 1993) (strip search for suspected drug sales); Williams ex rel. Williams v. Ellington, 936 F.2d 881, 884 (6th Cir. 1991) (search of student's person for suspected drug use).

${ }^{64}$ Bd. of Educ. of Indep. Sch. Dist. No. 92 of Pottawatomie Cnty. v. Earls, 536 U.S. 822, 831-32 (2002); Vernonia Sch. Dist., 515 U.S. at 657.

${ }^{65}$ Earls, 536 U.S. at 831-32.

${ }^{66} \mathrm{Id}$. at 831.

${ }^{67} \mathrm{Id}$. at 832 . 
minimal and the governmental interest high. ${ }^{68}$ In fact, the Court in Earls seemed to back away entirely from any requirement of a real governmental interest, holding that a "demonstrated problem of drug abuse...[is] not in all cases necessary to the validity of a testing regime." Instead, the Court allowed for a showing that simply "shores up" — a standard that appears to be decidedly vague — a special need for a suspicionless search. ${ }^{70}$

In its most recent foray into the schoolyard, the Supreme Court pulled back from its earlier decisions, acknowledging that students have a privacy zone that must be protected. ${ }^{71}$ In Safford United School District $v$. Redding, the Supreme Court held that a strip search of a student accused of hiding "contraband" Ibuprofen went too far. ${ }^{72}$ The student was suspected of dispersing prescription drugs to other students so administrators searched her bra and had her open her pants. ${ }^{73}$ No pills were found. The Court held that the search at its inception was justified because the principal had heard that the student was distributing pills to students. ${ }^{74}$ However, the scope of the ultimate search was found to be not reasonably related to the circumstances. ${ }^{75}$

The Court believed that school officials in Redding had sufficient suspicion to warrant a search of the young girl's backpack and outer clothing. There was ample evidence she had been involved in pill distribution. The search of her outer clothing and backpack were therefore not excessively intrusive. However, the Court held that pulling away the young girl's underwear went beyond the bounds of an appropriate search given the circumstances. ${ }^{76}$ Although the school officials testified that they did not, in fact, see anything when the girl pulled away her underwear, the Court held that the very possibility of exposure was enough to trigger a Fourth Amendment violation. ${ }^{77}$ What justified this finding were "subjective and reasonable societal expectations of personal privacy." to the reason for the search; that is, the grounds for the search-non-

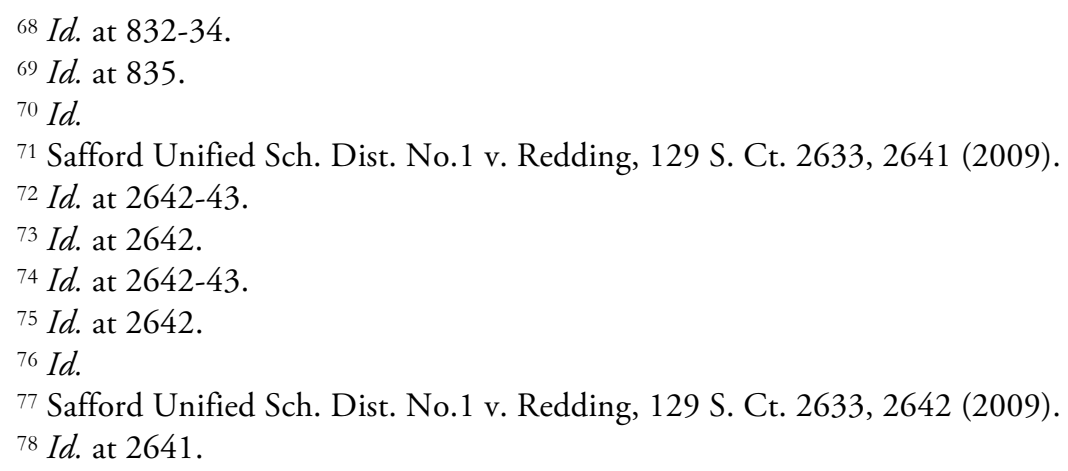


dangerous contraband-did not warrant such an intrusive search. ${ }^{79}$ The Court also took issue with the lack of particularized suspicion that the girl actually had drugs on her person. Without clear information that drugs were being secreted on the girl's body or other indication of actual danger, the Court held the search was inappropriate under the circumstances. $^{80}$

The Court acknowledged in Redding that societal norms and expectations contribute to an assessment of the expectation of privacy. ${ }^{81}$ Indeed, the Court went so far as to make a distinction between a student's exposure in a locker room-something students are accustomed to and therefore considered less invasive-and exposure for the sake of a search, which is understood to be more intrusive because it is not within a student's ordinary experience. ${ }^{82}$ In short, the Court found that adolescents' perceptions about exposing their bodies and their vulnerability due to natural self-consciousness demand particular protection. $^{83}$

\section{A. Defining What Is "Private"}

Permitting school searches that are reasonably related in scope and not "excessively intrusive in light of age and sex of the student" 84 leads to the question-what does "intrusive" in this context mean? In

${ }^{79} \mathrm{Id}$.

${ }^{80} \mathrm{Id}$. at 2643.

${ }^{81}$ In a very recent case, United States $v$ Jones, the Court held that placing a GPS device under a suspect's car without a warrant constituted a search that violates the Fourth Amendment. Scalia's opinion based the violation on the police officer's physical intrusion of a protected area - a trespassory intrusion. The Court divided on Scalia's approach to the analysis, not the ultimate holding. Scalia did not apply an "expectation of privacy analysis," focusing instead on a property analysis. In her concurring opinion, Justice Sotomayor addressed the privacy analysis and noted that the particular attributes of the GPS should be taken into account: "I would not assume that all information voluntarily disclosed to some member of the public for a limited purpose is, for that reason alone, disentitled to Fourth Amendment protection.” U.S. v. Jones, 132 S. Ct. 911, 957 (2012).

82 Safford Unified Sch. Dist. No.1 v. Redding, 129 S. Ct. 2633, 2642 (2009). See generally, Transcript of Oral Argument, Safford Unified Sch. Dist. No. 1 v. Redding, 129 S. Ct. 2633 (2009) (No. 08-479).

83 Redding, 129 S. Ct. at 2642. See generally, Transcript of Oral Argument, Safford Unified Sch. Dist. No. 1 v. Redding, 129 S. Ct. 2633 (2009) (No. 08-479).

${ }^{84}$ New Jersey v. T.L.O., 469 U.S. 325, 342 (1985). 
other words, what is a reasonable expectation of privacy for a high school student? ${ }^{85}$

Expectation of privacy analysis measures both an individual's subjective view and society's objective view of what is reasonable. ${ }^{86}$ Applying the subjective standard to a teenager poses a unique difficultly because, at least outwardly, a teenager's definition of what is private is a moving target. $^{87}$ If establishing the line for teenagers' subjective expectations of privacy were based on the type of information most teens post online or communicate via cell phone, the line might not exist at all. However, assuming that the type of private information that a teen is willing to put out electronically is an indication of what they believe is private is a mistake. ${ }^{88}$ One study that compared social media privacy settings between teens and adults found little variation indicating, as least

85 Bill O. Heder, The Development of Search and Seizure Law in Public School, 1999 B.Y.U. EDUC. \& L. J. 71, 81 (1999) ("The test for subjective and socially acceptable privacy expectations places immense discretionary and interpretive burdens upon the courts.").

86 Katz v. United States, 389 U.S. 347, 361 (1967) (Harlan, J., concurring). Justice Harlan's concurrence in Katz has since been adopted as the test applicable to Fourth Amendment claims.

${ }^{87}$ Leary, supra note 9, at 1043-44.

88 See, e.g., Anthony G. Amsterdam, Perspectives on the Fourth Amendment, 58 MINN. L. REV. 349, 404, 406 (1974) ("Because we are accustomed to having something approaching absolute privacy when we lock our outer doors, we tend to conceive of privacy as an absolute phenomenon and to denigrate the importance of degrees of privacy. To us it seems intuitively evident that anything a person does within sight or hearing of his neighbors or the general public is not private-and that, as to such things, it makes no difference whether they are observed by a neighbor or a policemanbecause we retire to our homes when we want real privacy. But if you live in a cheap hotel or in a ghetto flat, your neighbors can hear you breathing quietly even in temperate weather when it is possible to keep the windows and the doors closed. For the tenement dweller, the difference between observation by neighbors and visitors who ordinarily use the common hallways and observation by policemen who come into the hallways to 'check up' or 'look around' is the difference between all the privacy that his condition allows and none. Is that small difference too unimportant to claim fourth amendment [sic] protection? I myself do not think so, but the difficulty of making judgments of this sort and embodying them in administrable rules is evident."); see also Alice E. Marwick et al., Youth, Privacy and Reputation, 13 (Berkman Ctr. for Internet \& Soc'y, Research Publ'n No. 2010-5, 2010; Harvard Public Law, Working Paper No. 10-29, 2010), available at http://papers.ssrn.com/sol3/papers.cfm?abstract_id =1588163\#\#; Danh Boyd et al., Social Privacy in Networked Publics: Teens' Attitudes, Practices, and Strategies, A DECADE IN InTERnet TIME: SyMposium ON THE DYNAMICS OF THE INTERNET AND SOCIETY, Sept. 22, 2011, available at http://ssrn.com/abstract=1925128. 
in this limited study, that teens and adults share similar concerns about privacy. ${ }^{89}$

Teens are, by definition and developmental stage, risk-takers. ${ }^{90}$ Most adolescents do not have the capacity to think through the results of their actions. Thus, what they choose to put on their phones or publicize through social media should not serve as any kind of gauge of what they consider private. $^{91}$ The exhibitionist tendencies of teens probably have more to do with social norms and lack of maturity than any kind of renunciation of what they think should be private. If teenagers are in some sense unreasonable by nature, it might seem impossible to judge what is reasonable based on their behavior.

How, then, do we measure a teenager's subjective expectation of privacy? In Redding, Justice Souter tried to address this conundrum by considering the student's own subjective account of being embarrassed, humiliated, and frightened after a school administrator instructed the student to pull out her bra and the elastic on her pants. ${ }^{92}$ Souter also applied a "semi-objective" measure, holding that "the reasonableness of her expectation (required by the Fourth Amendment standard) is indicated by the consistent experience of other young people similarly searched, whose adolescent vulnerability intensifies the patent intrusiveness of the exposure." 93 This standard suggests the need to take into account the level of intrusiveness as it feels to a typical adolescent, rather than to a "reasonable" person. ${ }^{94}$ By this reasoning, establishing how intrusive a cell

${ }^{89}$ Researchers conducting a study for the Pew Research Center's Internet and American Life Project compared privacy settings on social media sites of teens and adults. The study demonstrated no significant variation in the settings of teens and their adult counterparts. Available at http://www.pewinternet.org///media//Files/Reports/2012/ PIP_Privacy_management_on_social_media_sites_022412.pdf.

${ }^{90}$ In Roper $v$. Simmons, the Supreme Court held that the death penalty as applied to juveniles under eighteen is cruel and unusual punishment. 543 U.S. 551, 569 (2005). The Court based its ruling, in part, on research showing the immature, impulsive, and poor decision-making skills of adolescents. Id.

${ }_{91}$ Chris Jay Hoofnagle et al., How Different Are Young Adults from Older Adults When it Comes to Information Privacy Attitudes and Policies? (Apr. 14, 2019), http://ssrn.com/abstract=1589864. This study collected and compared data from several age groups, the youngest of which was eighteen to twenty-four. The report concluded that young adults may share personal data not because they lack concern for their privacy, but because sharing their own data is a means of maintaining their social connections and adhering to social norms.

92 Safford Unified Sch. Dist. No.1 v. Redding, 129 S. Ct. 2633, 2641 (2009).

${ }^{3} \mathrm{Id}$. (emphasis added).

${ }^{94}$ In J.D.B. v. North Carolina, 131 S. Ct. 2394 (2011), the Supreme Court held that a child-suspect's age is relevant to whether they are in custody for Miranda purposes. In 
phone search is to a teenager is essential to setting appropriate limits on those searches.

\section{B. What Do Teens Do with Their Cell Phones?}

In 1973, when mobile phones were first invented, they were large cumbersome devices, ${ }^{95}$ weighing nearly two-and-a-half pounds. ${ }^{96}$ Today, advances in technology have led to cell phones and smart phones that are tiny, ${ }^{97}$ contain a wealth of information, and are used as a regular means of communication, particularly among teenagers. ${ }^{98}$ Smart phones, in particular, are a gateway to documents, passwords, Internet sites, and countless "apps"-all of which are reflections of, or extensions of, the student's life.

Research confirms that cell phones are now virtual appendages of teenagers. In a 2010 study, the Pew Research Center reported on comprehensive data about text messaging and teens. ${ }^{99}$ Most teens send roughly fifty text messages a day, or fifteen hundred texts a month. ${ }^{100}$ Cell phones have become the primary mode of communication for people aged twelve to seventeen. ${ }^{101}$

her opinion, Justice Sotomayor acknowledged that the Miranda analysis is an objective one that asks whether a "reasonable" person in the suspect's position would perceive that he or she was in custody. However, accounting for how a child perceives the situation is appropriate because what is reasonable to a child may not be reasonable to an adult. "In fact, in many cases involving juvenile suspects, the custody analysis would be nonsensical absent some consideration of the suspect's age. This case is a prime example. Were the court precluded from taking J. D. B.'s youth into account, it would be forced to evaluate the circumstances present here through the eyes of a reasonable person of average years. In other words, how would a reasonable adult understand his situation, after being removed from a seventh-grade social studies class by a uniformed school resource officer; being encouraged by his assistant principal to 'do the right thing'; and being warned by a police investigator of the prospect of juvenile detention and separation from his guardian and primary caretaker? To describe such an inquiry is to demonstrate its absurdity. Neither officers nor courts can reasonably evaluate the effect of objective circumstances that, by their nature, are specific to children without accounting for the age of the child subjected to those circumstances.” Id. at 2405.

95 Gerald Goggin, Cell PhONe Culture 20 (2006).

${ }^{96} I d$.

${ }_{97} \mathrm{Id}$.

${ }^{98} \mathrm{Id}$.

${ }^{99}$ Lenhart, supra note 8.

$100 \mathrm{Id}$. at 31.

101 Id. at 9. (Not surprisingly, "[w]ireless communication has emerged as one of the fastest diffusing media on the planet," giving birth to a "mobile youth culture"). 
In the Pew survey, many teens reported that they send text messages several times a day to exchange information privately and to have long conversations to discuss personal matters. Nearly threequarters of teens said their texts contain "personal matters."102 When asked, teens indicated that the cell phone is a "bonding resource."103

Teens naturally use their phones for more than just texting and calling. ${ }^{104}$ Of the seventy-five percent of teens who own cell phones, the majority uses their phones to take pictures and share those pictures with other teens. ${ }^{105}$ Other uses include playing music, playing games, exchanging videos, instant messaging, using the Internet, accessing social network sites, and using email. ${ }^{106}$

When it comes to using cell phones in schools, about two-thirds of teens said that they attend a school where they are allowed to have their phone with them, but are not allowed to use the phone in class. ${ }^{107}$ Only a quarter said that they attend a school where they are not allowed to have cell phones at all. ${ }^{108}$ Of teens that attend schools where classroom use is forbidden, some teens talked of teachers' own policies for keeping cell phone use to a minimum. ${ }^{109}$ For example, one high school student described a teacher who collects cell phones at the beginning of each class and returns them to students when class ends. ${ }^{110}$ Another student described a teacher who will take a phone from an offending student and read the message out loud to the entire class. ${ }^{111}$

\section{Current Application of Fourth Amendment to Cell PhONeS}

In general, courts recognize that users have a legitimate expectation of privacy in the content-based information on their cell phones. ${ }^{112}$ Cell phones contain a "wealth of private information" such as

${ }_{102} I d$. at 55.

${ }^{103} \mathrm{Id}$.

${ }^{104} \mathrm{Id}$. at 5.

${ }^{105}$ Lenhart, supra note 8, at 5.

$106 \mathrm{Id}$.

${ }^{107} I d$. at 81 .

${ }_{108} \mathrm{Id}$.

${ }^{109} I d$. at 82.

${ }_{110} \mathrm{Id}$.

111 Lenhart, supra note 8 , at 82.

112 Courts distinguish between "content-based" information and "coding" information. Content-based information consists of the subject matter of communications and stored data. Coding information consists of identifying or tracking information. See United States v. Zavala, 541 F.3d 562, 577 (5th Cir. 2008); Quon v. Arch Wireless Operating 
recent-call lists, emails, text messages, and photographs. ${ }^{113}$ A cell phone's ability to store this large amount of private information "gives users a reasonable and justifiable expectation of a higher level of privacy in the information they contain." 114 Because cell phone users typically have a legitimate expectation of privacy in their phone's contents, a search warrant is required for a search unless an exception to the warrant requirement exists. ${ }^{115}$ One such exception is the automobile exception, which allows police to search items inside a car that are within reach of an unsecured driver. ${ }^{116}$

When the issue of cell phone searches first arose, lower federal and state courts often evaluated cell phone searches in reference to either the "search incident to arrest" or automobile exception to the warrant requirement. In such instances, courts used the analogy that cell phones are "closed containers" similar to a purse or wallet. For example, in the 2005 case United States v. Cote, the federal district court in Northern Illinois reasoned that a cell phone is analogous to a wallet or an address book because it holds similar information. ${ }^{118}$ Because searches of wallets and address books had been allowed in past cases under the "incident to arrest" exception, the Illinois court held, without significant reasoning, that the same standard should apply to cell phones. ${ }^{119}$ In a 2007 case, United States $v$. Finley, the court upheld, with no reasoning, a search of the

Co., 529 F.3d 892, 905 (9th Cir. 2008); United States v. Finley, 477 F.3d 250, 259

(5th Cir. 2007); United States v. Quintana, 594 F. Supp. 2d 1291, 1299 (D. Fla. 2009); Connecticut v. Boyd, 992 A.2d 1071, 1083 (Conn. 2010); Ohio v. Smith, 920 N.E.2d 949, 955 (Ohio 2009).

113 Quintana, 594 F. Supp. 2d at 1299 (citing Zavala, 541 F.3d at 577).

114 Smith, 920 N.E.2d at 955.

115 Quintana, 594 F. Supp. 2d at 1299. Police officers that make a lawful arrest do not need a warrant to conduct a search incident to that arrest as long as the search is for evidence of the arrestee's crime. Chimel v. California, 395 U.S. 752 (1969); New York v. Belton, 453 U.S. 454 (1981); Arizona v. Gant, 556 U.S. 332 (2009).

116 Gant, 556 U.S. at 351.

117 Finley, 477 F.3d at 260; United States v. Cote, No. 03CR271, 2005 WL 1323343, at *6 (N.D. Ill. May 26, 2008); United States v. James, No. 1:06CR134 CDP, 2008 WL 1925032, at *4 (E.D. Mo. April 29, 2008); see also California v. Acevedo, 500 U.S. 565 (1991) (holding that police may search an automobile and the containers within it where they have probable cause to believe that evidence or contraband is contained); New York v. Belton, 453 U.S. 454 (1981) (holding that police may search containers, whether open or closed, located within arrestee's reach as a valid search incident to arrest).

118 Cote, 2005 WL 1323343 at *6.

${ }^{119} \mathrm{Id}$.; see also United States v. Rodriguez, 995 F.2d 776 (7th Cir. 1993) (explaining that a wallet and address book are part of a valid search incident to arrest). 
defendant's cell phone contents because it was pursuant to an arrest. ${ }^{120}$ Other similar cases offered limited reasoning or no reasoning at all, instead simply finding that cell phones are containers. ${ }^{121}$

Other courts have recognized that cell phones are unique repositories that contain extensive personal information and therefore require different treatment. In U.S. $v$. Park, a federal district court in Northern California held that a search of the defendant's cell phone went "far beyond the original rationales for searches incident to arrest." " In this 2007 case, the court also noted that the search was not conducted to preserve evidence or to ensure officer safety. ${ }^{123}$ Cell phones, the court said, are not like pagers or address books; unlike those items, cell phones store an "immense amount of private information" including "incoming and outgoing calls, address books, calendars, voice and text messages, email, video, and pictures." 124 Information contained in modern electronic storage devices "renders a search of their contents substantially more intrusive than a search of the contents of a lunchbox or other tangible object." ${ }^{, 25}$ The court did not explicitly address the cellphone-as-container theory, but it embraced the alternate view that cell phones are unique instruments whose private contents are such that searches need to meet the higher standard applicable to a personal computer. ${ }^{126}$

Similarly, in Obio v. Smith, a 2009 case, police searched a suspected drug dealer's cell phone after his arrest. ${ }^{127}$ The court disagreed

120 United States v. Finley, 477 F.3d 250, 260 (5th Cir. 2007).

121 See United States v. Deans, 549 F. Supp. 2d 1085, 1094 (D. Minn. 2008) (citing Belton and Finley to hold that police can search any "container" in a vehicle-and that includes cell phones); see also United States v. Fierros-Alvarez, 547 F. Supp. 2d 1206, 1214 (D. Kan. 2008) (stating that courts usually will not "suspend general Fourth Amendment jurisprudence on exceptions to the search warrant requirement simply because the container is a cellular telephone phone”); Connecticut v. Boyd, 992 A.2d 1071, 108889 (Conn. 2010) ("When the automobile exception applies, police may also search closed containers located within the automobile . . . even if it's a cell phone"); James, 2008 WL 1925032 at *4; People v. Diaz, 244 P.3d 501, 510 (Cal. 2011) (holding that police lawfully searched contents of cell phone found on a defendant's person incident to arrest because the phone was "immediately associated with the defendant's person").

122 No. CR 05-375 SI, 2007 WL 1521573, at *8 (N.D. Cal. May 23, 2007).

${ }^{123} \mathrm{Id}$.

124 Id.

125 Id.

${ }^{126}$ Id.; see also United States v. Valdez, No. 06-CR-336, 2008 WL 360548, at *3 (E.D. Wis. Feb. 8, 2008).

126 Ohio v. Smith, 920 N.E.2d 949, 950 (Ohio 2009).

${ }^{127}$ Id. 
with the holdings in Finley and other prior Ohio cases when it announced that cell phones are not closed containers for the purposes of Fourth Amendment analysis. ${ }^{128}$ The court reasoned that in Belton the U.S. Supreme Court defined "container" as "any object capable of holding another object." 129 Such a definition "implies that the container must actually have a physical object within it." 130 The Ohio court made the distinction that, although cell phones may be said to "contain" information, they do not in fact contain anything physical. ${ }^{131}$ Treating them as containers is therefore based merely on a semantic coincidence and does not recognize their special capabilities as repositories of personal information. "Even the more basic models of modern cell phones" are capable of storing an abundance of electronic information "wholly unlike any physical object found within a closed container." After establishing that cell phones are not containers, the court went on to promulgate a new standard for cell phone searches incident to arrest: once police seize a cell phone found during an arrest, they have satisfied their immediate interest in collecting and preserving evidence. Any further search of the phone's highly private contents must only be conducted with a warrant. ${ }^{133}$

\section{A. How Are Courts Ruling on Current Public School Policies?}

While cell phones have certainly increased the speed and ease of useful communication and coordination, the growing number of school students who bring phones to school has sparked a variety of problems. Students may text during class, use their phones to cheat on exams, bully their peers, arrange illegal drug sales, and conspire to flout school regulations. ${ }^{134}$ Even when schools ban cell phones, almost two-thirds of

\footnotetext{
${ }^{128} \mathrm{Id}$. at 954 .

${ }^{129}$ Id. (citing New York v. Belton, 453 U.S. 454, 460 (1981)).

${ }^{130}$ Id. See United States v. Chan, 830 F. Supp. 531, 534 (N.D. Cal. 1993) (holding that a pager is a closed container); United States v. Ortiz, 84 F.3d 977, 984 (7th Cir. 1996) (agreeing with Chan).

131 Smith, 920 N.E.2d at 955.

132 Id. at 954.

133 Id. at 955. Contra Fawdry v. State, No. 1D10-0896, 2011 WL 1815328, *3 (Fla. Dist. Ct. App. 2011) (disagreeing with the Smith court, holding that the digital information contained in a cell phone fits the description of objects found in a closed container, albeit in an intangible form).

${ }_{134}$ Lenhart, supra note 8, at 1, 5, 9; Zach Miners, One Third of Teens Use Cellphones to Cheat in School, U.S. NEWS - ON EDUCATION BLOG (June 23, 2009),
} 
students at such "no phone" schools bring them anyway. ${ }^{135}$ Compounding the problem, parents do not always support school administrators seeking to control cell phone use. In 2007, for example, parents of New York City public school students sued the school department after it banned cell phones at school. ${ }^{136}$ One basis for the court's opinion siding with the schools was that students simply do not have the maturity or self-control to resist use, and thus enforcement of a limited use policy would be too difficult. ${ }^{137}$

Schools often address the problem by instituting confiscation policies. ${ }^{138}$ Some schools go further and sanction searches of cell phones once they are confiscated. ${ }^{139}$ When such policies exist, courts have

http://www.usnews.com/education/blogs/on-education/2009/06/23/one-third-of-teensuse-cellphones-to-cheat-in-school.

135 Id. at 83.

136 Price v. New York City Bd. of Educ., 837 N.Y.S.2d 507 (Sup. Ct. 2007), affd 855 N.Y.S.2d 530 (App. Div. 2008).

137 Id. at 519.

138 A typical confiscation policy: "Students are not permitted to use or have a cell phone in sight upon arrival on campus. Students are allowed to use their cell phone for reasonable communication purposes in or out of the building after dismissal. If students are found using a cell phone or if a cell phone is seen or heard during the previously stated school hours, the cell phone will be confiscated and turned over to the school administration. For after school activities, the use of such devices shall be at the discretion of the activity sponsor." Bedford County Schools, Cell Phone Policy (emphasis added), available at http://www.bedfordk12tn.com/education/components/scrapbook/default.php?sectio ndetailid=9452; see also Boston Public Schools, Guide to the Boston Public Schools 51 (2010), available at http://www.bostonpublicschools.org/files/bps_guide_12_ english.pdf; Charlotte-Mecklenburg County Schools, Code of Conduct 9 (2011), available at http://www.cms.k12.nc.us/parents/resources/Documents/CODEOF CONDUCT2011ENG.pdf; Detroit Public Schools, Rights and Responsibilities of Students in the Detroit Public Schools 15-16 (2011), available at http://detroitk12.org/ resources/students/codeOfConduct/Student_Code_of_Conduct.pdf.

139 Sharon Salyer, Mukilteo Schools May Check Students' Cell Phones, HeraldNet, Jan. 24, 2011, available at http://www.heraldnet.com/article/20110124/NEWS01/ 701249945; Marlee Ginter, District Ponders Subjecting Students to Cell Phone Search, KOMO NEws, Aug. 16, 2010, available at http://www.komonews.com/ news/local/100809309.htm; Katie McVicker, Checking for Sexting: Oak Harbor School Board Policy Would Let School Officials Search Students' Cell Phones, WHIDBEY NeWsTimeS, Aug. 16, 2010, available at http://www.pnwlocalnews.com/whidbey/ wnt/news/100655619.html; Tony Marerro, Hernando Schools Students' Cell Phones Can Be Searched, Board Says, TAMPA BAY TIMES, May 5, 2010, available at http://www.tampabay.com/news/education/k12/hernando-schools-students-cell-

phones-can-be-searched-board-says/1092539; Lanie Barron, Yes, They Can Read Your Texts, ERnest W. SEAholm Highlander, Sept. 16, 2008, available at 
authorized searches of confiscated phones where there is reasonable suspicion of a school rule violation or violation of law. ${ }^{140}$ However, such searches are being challenged with greater frequency. ${ }^{141}$

The courts have responded to the growing number of challenges to student cell phones searches by applying the T.L.O. two-step approach: first, examining the justification for the search, and next, deciding whether the scope of the search was reasonable. ${ }^{142}$ While courts are willing to find that the searches are justified in their inception, they are less willing to allow school officials to search the content of a phone. For example, in 2006, the federal district court in Pennsylvania took up the issue in Klump v. Nazareth Area School District. In Klump, a teacher confiscated a student's cell phone after it fell out of his pocket, pursuant to a school policy prohibiting the use or display of cell phones. ${ }^{143}$ Once it was taken away, school officials accessed the student's text messages and voice mail and called nine numbers listed in the student's contact list to see if the students would violate cell phone policy by answering their phones. ${ }^{144}$ The school officials also engaged in a text message conversation with the student's younger brother. ${ }^{145}$ At some point a text was received from the student's girlfriend that read, "Get me a ***in tampon"146 — an apparent reference to a large marijuana cigarette. ${ }^{147}$

http://seaholmhighlander.com/community/seaholm-high-school/250-yes-they-can-readyour-texts; Leonard Glenn Crist, Board Passes Cell Phone Policy, SALEMNEWS.NET, June 13, 2008, available at http://www.salemnews.net/page/content.detail/id/502774/Boardpasses-cell-phone-policy.html.

${ }_{140}$ Mendoza v. Klein Indep. Sch. Dist., No. H-09-3895, slip op. at 22 (S.D. Tex. Mar. 15, 2011). See also ACLU of California, Hello! Students Have a Right to Privacy in Their Cell Phones: Indiscriminate Cell Phone Searches Violate Students' Privacy Rights (Sept. 2011), available at http://www.aclusandiego.org/site/wp-content/uploads/2012/05/HE-L-L-O-student-cell-phone-rights.pdf; Authority to Seize Students' Cell Phones, Op. Va. Att'y Gen. (Nov. 24, 2010), available at http://www.ag.virginia.gov/ Opinions\%20and\%20Legal\%20Resources/Opinions/2010opns/10-105-Bell.pdf.

141 See, e.g., Mendoza v. Klein Indep. Sch. Dist., No. H-09-3895, slip op. at 22 (S.D. Tex. Mar. 15, 2011); J.W. v. DeSoto County Sch. Dist., 2:09-CV-00155-MPM, 2010 WL 4394059 (N.D. Miss. Nov. 1, 2010); N.N. v. Tunkahannock Area Sch. Dist., 801 F. Supp. 2d 312 (M.D. Penn. 2011).

142 Bernard James, Safe Schools, Cell Phones, and the Fourth Amendment, NASRO J. OF SCH. SAFETY, Winter 2009, available at http://law.pepperdine.edu/academics/ faculty/publications/James-NASROCellPhoneLaw.pdf.

${ }^{143}$ Klump v. Nazareth Area Sch. Dist., 425 F. Supp. 2d 622, 627 (E.D. Penn. 2006).

${ }^{144} \mathrm{Id}$.

${ }^{145} \mathrm{Id}$.

${ }^{146} I d$. at 631.

${ }^{147} \mathrm{Id}$. 
The student in Klump sued the school claiming violations of state and federal wiretap laws, invasion of privacy, and Fourth Amendment violations. ${ }^{148}$ The school moved to dismiss the claims, countering, among other things, that it was not subject to a Fourth Amendment claim under immunity laws that shielded state officials from certain kinds of federal lawsuits. ${ }^{149}$

The Klump court denied the school's motions to dismiss. ${ }^{150}$ Applying T.L.O.'s two-part test, the court found that seizing the phone was justified at its inception because the student had violated a school rule. ${ }^{151}$ However, school officials were not justified in searching the contents of the phone, nor was it permissible to use the phone as a tool to stimulate additional violations of school policy. School officials had no reason to think that the student was transgressing school policy at the time of the confiscation. ${ }^{152}$ The court therefore disallowed the search because the text about drug activity was not apparent to officials until after they initiated the search of the phone. ${ }^{153}$

Similarly, in a 2010 Texas case, Mendoza v. Klein Independent School District, a teacher confiscated an eighth grader's phone after observing her looking at it with some friends. ${ }^{154}$ Because of the students' guilty reactions when they were confronted, the teacher inferred that they were probably looking at something inappropriate for a school setting. ${ }^{155}$ The teacher took the phone, searched through sent text messages, and found nude photos of the student. ${ }^{156}$ The student confessed that she had sent the photos to her boyfriend because he had sent similar photos to her. ${ }^{157}$ The student was suspended and assigned to a disciplinary program. ${ }^{158}$ She subsequently sued the school for violating her Fourth Amendment rights

\footnotetext{
$148 \mathrm{Id}$.

149 Klump v. Nazareth Area Sch. Dist., 425 F. Supp. 2d 622, 640 (E.D. Penn. 2006) (qualified immunity protects public officials from lawsuits brought under the Constitution unless the conduct violates clearly established rights of which a reasonable person would have been aware).

${ }^{150} \mathrm{Id}$. at 638.

151 Id. at 640 .

$152 \mathrm{Id}$.

${ }^{153} I d$.

154 Mendoza v. Klein Indep. Sch. Dist., No. H-09-3895, slip op. at 2 (S.D. Tex. Mar. 15, 2011).

155 Id. at 3 .

156 Id. at 3-4.

157 Id. at 4.

158 Id. at 5-6.
} 
and for intentional infliction of emotional harm. ${ }^{159}$ Like the Klump defendant, the school in this case claimed immunity from liability under state law, thus triggering review of the Fourth Amendment constitutional claim. ${ }^{160}$

In Mendoza, the court found that the search was justified at its inception because the student had claimed she was not using the phone, but the teacher's observations suggested otherwise. ${ }^{161}$ Accordingly, the teacher was justified in checking to see if the student had violated school policy by sending a text during school. ${ }^{162}$ However, the court denied the school's motion for summary judgment, holding that a jury could find that opening the texts on the phone was not reasonably related to the initial justification for searching the phone. ${ }^{163}$

By contrast, in J.W. v. DeSoto County School District, a twelve-yearold boy was expelled from school in 2008 for suspected gang activity after his cell phone, confiscated for in-class use, was found to contain a picture of a friend holding what turned out to be a BB gun, and other pictures depicting alleged gang clothing. ${ }^{164}$ The student sued the Mississippi school district claiming that he was unlawfully expelled, and the case came before the court on the issue of whether searching the phone violated clearly established law, thereby foreclosing the school's immunity from suit. ${ }^{165}$ The court found that the search of the student's cell phone was not unlawful because the student had brought it to school and used it against school rules. These acts diminished the student's expectations of privacy. ${ }^{166}$ The DeSoto court distinguished the case from Klump, describing the Pennsylvania school's search as a veritable "fishing expedition" into the student's personal life. ${ }^{167}$ Here, the court said, the Mississippi school's actions were "limited" to only looking at the student's photos. ${ }^{168}$ The case was settled in February 2011. ${ }^{169}$

\footnotetext{
${ }^{159} I d$. at $7-8$.

${ }_{160}$ Mendoza v. Klein Indep. Sch. Dist., No. H-09-3895, slip op. at 8 (S.D. Tex. Mar. 15, 2011); Tex. Educ. Code Ann. \$22.0511 (West 2006).

161 Mendoza, slip op. at 22 (S.D. Tex. Mar. 15, 2011).

162 Id. at $22-23$.

$163 \mathrm{Id}$. at 27.

164 2:09-CV-00155-MPM, 2010 WL 4394059, at*2 (N.D. Miss. Nov. 1, 2010).

$165 \mathrm{Id}$.

166 Id.

167 Id. at ${ }^{*} 5$.

168 Id.

169 Press Release, ACLU, Mississippi School District to Clarify Gang Policy as Part of Settlement of ACLU Lawsuit (Feb. 9, 2011), available at http://www.aclu.org/racialjustice/mississippi-school-district-clarify-gang-policy-part-settlement-aclu-lawsuit.
} 
The ACLU has also taken up the issue of cell phone searches. In 2007, the ACLU stepped into a dispute at a Colorado school district. ${ }^{170}$ School administrators had been taking cell phones after minor infractions and then reading the texts - a practice that had been authorized by the school district's legal counsel. ${ }^{171}$ The ACLU argued that the searches violated state law as well as the Fourth Amendment. ${ }^{172}$ In response, the school district agreed to limit its practice and instituted new rules that require administrators to get student or parental permission before searching a cell phone unless there is an imminent threat to public safety. $^{173}$

The ACLU of California made a similar complaint to a California school district in 2008 after a school administrator confiscated a student's phone while he was talking to his mother. ${ }^{174}$ The administrator allegedly accessed three weeks of prior texts messages that included personal communications with the student's mother. ${ }^{175}$ Pursuant to the ACLU's action, the school administration agreed that school officials would not search the text messages of confiscated cell phones unless they had a reasonable suspicion of a violation of law or school rules. The new policy also limited the scope of the search to information pertaining directly to the alleged infraction that led to the seizure of the phone. ${ }^{176}$

In 2010, the ACLU of Pennsylvania sued a school district after a school principal scrolled through a student's phone and found "explicit" photos, which he turned over to law enforcement. ${ }^{177}$ The case was settled

170 See Letter from American Civil Liberties Union to Bd. of Educ., Boulder Valley Sch. Dist. (Oct. 10, 2007) (on file with author), available at http://aclu-co.org/ sites/default/files/BVSD_ACLU_10-10-07.pdf.

${ }^{171} \mathrm{Id}$.

${ }^{172} \mathrm{Id}$.

173 Press Release, ACLU, ACLU Applauds Boulder Valley School District's Decision to Limit Searches of Students' Cell Phone Text Messages (Apr. 21, 2008), available at http://aclu-co.org/news/aclu-applauds-boulder-valley-school-district\%E2\%80\%99sdecision-to-limit-searches-of-students $\%$ E2\%80\%99-cell-pho.

${ }^{174}$ Letter from American Civil Liberties Union to Linden Unified Sch. Dist. Bd. of Trs. (Mar. 3, 2008) (on file with author), available at http://www.aclunc.org/docs/youth/303-08_aclu_ltr_to_linden_school_district.pdf.

$175 \mathrm{Id}$.

176 Press Release, ACLU, School District Changes Its Unconstitutional Cell Phone Search Policy (Apr. 16, 2008), available at http://www.aclunc.org/cases/other_legal _advocacy/school_district_changes_its_unconstitutional_cell_phone_search_policy.sht $\mathrm{ml}$ ?ht $=$.

177 Complaint, N.N. v. Tunkhannock Area Sch. Dist., 801 F. Supp. $2 d 312$ (M.D. Pa. May 20, 2010) (No. 10-CV-01080). 
with the school agreeing to pay the plaintiff $\$ 33,000^{178}$ and to formulate better guidelines on cell phone searches. ${ }^{179}$

As the courts grapple with how to apply the reasonableness test to searches of student cell phones, schools are struggling to cope with the implications of widespread cell phone ownership and student use. Outright bans appear to be of little practical use, as phones can readily be concealed. $^{180}$ Confiscation-for-use policies are the norm, but the circumstances governing how school officials can search confiscated cell phones and the manner in which they do so are still unsettled. As previously noted, students do not enjoy the same level of Fourth Amendment protection as other people, so searches of their cell phones have fallen into a gray zone that begs for clearer definition. The increasing pace of student versus school litigation and the more frequent involvement of the ACLU suggest that some definitive resolution of this question is not far off. ${ }^{181}$

\section{Cell Phone Searches Should Require a Search Warrant}

178 Press Release, ACLU, ACLU Settles Student-Cell-Phone-Search Lawsuit With Northeast Pennsylvania School District (Sep. 15, 2010), available at http://www.aclupa.org/pressroom/aclusettlesstudentcellphon.htm.

${ }^{179} \mathrm{Id}$.

180 A Pennsylvania school banned students from wearing Uggs to school because they were secreting cell phones inside the boots instead of following school policy and leaving the phones in their lockers. PA Middle School Bans Ugg Boots, NewsY.COM, Jan. 30, 2012, http://www.newsy.com/videos/pa-middle-school-bans-ugg-boots/.

181 Eric, Stevick, Mukilteo Schools OK Rules on Cell Phones, ThE DAILY Herald, Jan. 24, 2011, available at www.heraldnet.com/article/20110125/NEWS01/701259800; Katie McVicker, ACLU Hits Proposed Oak Harbor High School Cell Phone Policy, WhidBey News Times, Aug. 31, 2010, available at http://www.seattlepi.com/ default/article/ACLU-hits-proposed-Oak-Harbor-High-School-cell-887073.php;

Katherine Leal Unmuth, Irving School Board Supports Decision to Search Student's Cell Phone Text Messages Dallas School District, DALlas NeWS - IRVING Blog (Aug. 3, 2010, 8:00 AM), http://irvingblog.dallasnews.com/archives/2010/08/post-7.html; Lanie Barron, Yes, They Can Read Your Texts, SeAholm Highlander, Sept. 16, 2008, available at http://seaholmhighlander.com/community/seaholm-highschool/250-yes-they-can-read-your-texts; Brenda Pedraza-Vidamour, Schools Can Search Cell Phones, Newnan Times Herald, Sept. 6, 2008, available at http://www.timesherald.com/education/Schools-can-search-cell-phones--541309; Leonard Glenn Crist, Board Passes Cell Phone Policy, SALEM NEWS, June 13, 2008, available at http://www.salemnews.net/page/content.detail/id/502774/Board-passes-cell-phone-

policy.html. The Virginia Attorney General issued an advisory opinion on November 24, 2010 stating that "reasonable suspicion" is the applicable standard regarding whether school officials can search student's cell phones. Op. Va. Att'y Gen., supra note 140 . 
Most schools appear to adhere to a "reasonable suspicion" standard with respect to cell phone searches when they suspect that a law or school policy has been broken. However, it is not always clear what types of evidence justify reasonable suspicion. For example, if a student is caught texting in class, that in itself is a violation of school policy and clearly justifies confiscation, but does the conduct justify a search of the cell phone? "Reasonable suspicion" is a standard applied by police as justification for a "Terry" stop-a stop-and-frisk of an individual suspected of criminal activity. ${ }^{182}$ In this context, "reasonable suspicion" means that a "police officer must be able to point to specific and articulable facts which, taken together with rational inferences from those facts, reasonably warrant that intrusion." 183 Whether reasonable suspicion exists will depend on the "totality of the circumstances" and the officer's own experience and expertise. ${ }^{184}$ Courts sanction this lesser standard because, though circumstances warrant some intrusion given officer safety or crime prevention concerns, the intrusion to the individual is correspondingly minimal when compared to a full-blown arrest or search. ${ }^{185}$

The problem with applying the "reasonable suspicion" standard to a student cell phone search is that the level of intrusion is far higher than the analogous "pat down" or brief seizure of a suspect. As numerous cases demonsrate, searching a cell phone is likely to uncover information or images that are highly personal. Adolescents' lives revolve around communication. Just as Justice Souter in Redding acknowledged that a teenage suspect's sensibilities needed to be taken into account when contemplating a strip search, ${ }^{186}$ the same justification can reasonably be extended to student cell phone searches. Students may feel that the contents of their cell phones, with all the photos, texts, appointments and other personal information, are as private to them as their bodies themselves and should therefore be afforded a high level of acknowledged privacy. ${ }^{187}$

182 Terry v. Ohio, 392 U.S. 1, 22 (1968).

${ }^{183} \mathrm{Id}$.

184 U.S. v. Caraballo, 595 F.3d 1214 (11th Cir. 2010).

185 Terry, 392 U.S. at 24

186 Safford Unified Sch. Dist. No.1 v. Redding, 129 S. Ct. 2633, 2641 (2009).

${ }^{187}$ See Christopher Slobogin, Is the Fourth Amendment Relevant in a Technological Age? (Vanderbilt Public Law, Research Paper No. 10-64, 2011; Vanderbilt Law and Economics Research Paper No. 10-54, 2011) suggesting that a proportionality principle should apply to virtual searches whereby the justification for the search is calibrated to the search's impact on the affected party), available at http://papers.ssrn.com/ sol3/papers.cfm?abstract_id=1734755\#\#. 
This position is not contrary to the goal of maintaining safety. Whereas cell phones are not inherently dangerous, they may be used to further criminal activity or rule-breaking. In this case, evidence of illicit activity stored on a cell phone is not time-sensitive. While a strip search might be warranted immediately in order to prevent a student from disposing of evidence, information on a confiscated cell phone can be preserved until a warrant is obtained. Tighter restrictions on cell phone searches would not hamper administrators from performing other searches if they had reason to believe that a student was involved in illegal activity; this would remain consistent with a school's mandate to assure student safety and wellbeing. Similarly, if a student is suspected of using a cell phone for cheating or bullying, administrators may confiscate the cell phone and continue questioning the student. The results of the investigation may lead to a punitive sanction or, in the case of bullying, the administrators may seek a warrant. ${ }^{188}$

Justifying a warrantless cell phone search with a subjective "reasonable suspicion" standard in the school setting ignores a fundamental aspect of students and their privacy. Students' freedoms are already restricted because they are compelled by law to go to school and their in-school lives are governed by school regulations. ${ }^{189}$ Add to the mix that the majority of students carry cell phones (often at parents' request), ${ }^{190}$ and that young people may lack judgment and discretion concerning what they store in their phones. Given these conditions, allowing school officials wide latitude to perform searches of cell phones

188 Given that cell phones can be used for conduct like cheating and bullying, one can't help but wonder what the true disadvantages are for prohibiting cell phones in school all together.

189 William G. Buss, The Fourth Amendment and Searches of Students in Public Schools, 59 IOWA L. REV. 739, 773 (1974). In this early analysis of school search and seizure law, Buss argues for clearer recognition that school administrators should be understood as acting on behalf of, or in cooperation with, police. Particularly in cases of suspected criminal violations, Buss suggests that excusing the warrant requirement goes against the Fourth Amendment. Id.; see also New Jersey v. T.L.O., 469 U.S. 325, 336 (1985).

190 Parents in New York actually sued a school district after cell phones were banned claiming that it was a violation of constitutional rights and that, because they were unable to reach their children by phone, their safety was being endangered. Jennifer Medina, Court Upholds School Cellphone Ban, N.Y. TiMES - CITY ROOM BlOG (Apr. 22, 2008, 6:21 PM), http://cityroom.blogs.nytimes.com/2008/04/22/court-upholdsschool-cellphone-ban/; see also National School Safety and Security Services Website, Cell Phones and Text Messaging in Schools, http://www.schoolsecurity.org/ trends/cell_phones.html (parents have lobbied school boards to reverse cell phone bans based on safety concerns). 
violates fundamental Fourth Amendment principles. ${ }^{191}$ School administrators naturally assume authority for younger children under an in loco parentis paradigm, but the natural parental qualities of tolerance, understanding, and permanence recede as administrators are faced with the management of adolescents. While educators may still guide their older students with care and devotion, the modern high school must necessarily adopt a law enforcement model to cope with the range of student misbehavior. Schools have increased security procedures and staff; metal detectors, school police officers (known as SROs), random searches of students, and zero tolerance policies are now common in many public schools. . ${ }^{192}$ Indeed, in T.L.O., the Supreme Court recognized that "in carrying out searches and other disciplinary functions pursuant to such policies, school officials act as representatives of the State, not merely as surrogates for the parents."193

A school administrator should therefore not be able to operate like a magistrate and render decisions on cell phone searches in school. The purpose of the warrant requirement is to have a "neutral and detached" magistrate, i.e., a disinterested party, draw reasonable inferences from evidence to determine if an individual's Fourth Amendment protections can be justifiably waived. ${ }^{194}$ A judicial officer who reviews a warrant request should be severed and disengaged from

191 This view is not out of line with the Supreme Court's earlier recognition of student rights in school. In Tinker v. Des Moines Indep. Cmty. Sch. Dist., a case decided well before T.L.O. or Redding, the Court acknowledged that though students are subject to a different standard, they must still be viewed as persons under the Constitution. "School officials do not possess absolute authority over their students. Students in school as well as out of school are 'persons' under our Constitution. They are possessed of fundamental rights which the State must respect, just as they themselves must respect their obligations to the State.” 393 U.S. 503, 511 (1969).

192 Aaron Sussman, Learning in Lockdown: School Police, Race, and the Limits of Law, 59 UCLA. L. REV. 788, 793 (2012); Barry C. Feld, T.L.O. and Redding's Unanswered Fourth Amendment Questions: Few Rights and Fewer Remedies, 80 Miss. L.J. 847, 884 (2011) ("In the 1980s, police departments began to assign sworn police officersSROs - to schools to combat the scourge of drugs and in the 1990s to provide heightened security after high-profile school shootings. Local law enforcement agencies typically assign school resource officers (armed and uniformed police officers) to schools where they perform traditional law enforcement duties-patrolling campus, investigating criminal allegations, and dealing with students who violate school rules or the law."); see also Randall Beger, Expansion of Police Power in Public Schools and the Vanishing Rights of Students, 29 SOC. JUST. 119 (2002).

193 New Jersey v. T.L.O., 469 U.S. 325, 336 (1985).

194 United States v. Karo, 468 U.S. 705, 717 (1984) (quoting Johnson v. United States, 333 U.S. 10, 13-14 (1948)). 
the activities of law enforcement and have the capacity to determine probable cause. ${ }^{195}$

Any argument that a school administrator can make a decision as a neutral and disinterested party is without merit. Assuming that the school does serve in some capacity as a stand-in for a parent, it is hard to reconcile that status with someone who is also neutral and disinterested. ${ }^{196}$ More to the point, given that school administrators (or school resource officers) are enforcers charged with finding and punishing violations, their role could hardly be viewed as neutral. ${ }^{197}$ The principal or administrator who authorizes or conducts the search will likely be the one to impose the sanction on the student. Moreover, the administrator is tasked with reducing violations, and may even be under pressure to do so from a school board or parent group.

Requiring warrants to search a student's cell phone would admittedly restrict the discretion the Supreme Court has given schoolsa move that might seem ill-advised given concern about in-school crime, drug use, and violence. However, statistics do not support the contention that incidences of drugs and violence are increasing in schools. ${ }^{198}$

195 Shadwick v. Tampa, 407 U.S. 345, 350-52 (1972).

${ }^{196}$ School officials rendering decisions on the legality of searching one of their students invokes the same problem recognized by the Supreme Court in Coolidge v. New Hampshire, where the justices held that the New Hampshire Attorney General could not issue search warrants because he was not neutral and detached. 403 U.S. 443, 450 (1971) ("Without disrespect to the state law enforcement agent here involved, the whole point of the basic rule so well expressed by Mr. Justice Jackson is that prosecutors and policemen simply cannot be asked to maintain the requisite neutrality with regard to their own investigations-the 'competitive enterprise' that must rightly engage their single-minded attention.").

197 See Lo-Ji Sales, Inc. v. New York, 442 U.S. 319, 327 (1979) (Invalidating a search warrant signed by a Town Justice because "he was not acting as a judicial officer but as an adjunct law enforcement officer").

198 According to the Center for Disease Control (CDC): "While shocking and senseless shootings give the impression of dramatic increases in school-related violence, national surveys consistently find that school-associated homicides have stayed essentially stable or even decreased slightly over time. According to the CDC's School Associated Violent Death Study, less than 1 percent of all homicides among school-age children happen on school grounds or on the way to and from school. So the vast majority of students will never experience lethal violence at school." CDC Website, School Violence: Data \& Statistics, CDC.GOV (Jan. 4, 2011), http://www.cdc.gov/violenceprevention/ youthviolence/schoolviolence/data_stats.html; CDC Youth Risk Behavior Surveillance System, Trends in the Prevalence of Behaviors that Contribute to Violence on School Property, National YRBS 1991-2011, available at http://www.cdc.gov/HealthyYouth/ yrbs/pdf/us_violenceschool_trend_yrbs.pdf. 
According to the Center for Disease Control, the most recent survey data (through 2009) shows that drug and tobacco use on school property is flat and that neither the sale of drugs nor violence is on the increase. ${ }^{199}$ The decrease is part of an overall decline in both youth and adult crime. A warrant requirement that allows for an exception in emergency situations involving the health and safety of students would cover circumstances where examination of phone messages or data could prevent imminent harm.

Such an exception is not without ample precedent. The Supreme Court has carved out numerous exigencies justifying a warrantless search. ${ }^{200}$ Underlying these exceptions is an acknowledgment that the warrant requirement must give way when there is an immediate risk of physical harm or destruction of evidence. In the school context, maintaining safety is of paramount concern. Thus, when school administrators have credible, reliable information that a threat of imminent harm necessitates ascertaining information from a student's cell phone, they should be permitted to search without a warrant. ${ }^{201}$ But anything less than such an immediate and particularized threat should not suffice. If there is no immediate threat, the phone should be removed from the student's possession and preserved until a warrant is obtained. A cell phone and its data can be preserved while authorities notify the police, who have the option to get a warrant. ${ }^{202}$

199 See supra note 198; Youth Risk Behavior Surveillance - United States, 2009, MORBIDITY AND MORTALITY WEEKLY REP., Vol. 59, June 4, 2010, available at http://www.cdc.gov/mmwr/pdf/ss/ss5905.pdf; National Center for Education Statistics Website, Indicators of School Crime and Safety: 2011, available at http://nces.ed.gov/programs/crimeindicators/crimeindicators2011/key.asp.

${ }^{200}$ Kentucky v. King, 131 S. Ct. 1849, 1856 (2011) (upholding exigent circumstances exception where officers do not create exigency through Fourth Amendment violation); Brigham City v. Stuart, 547 U.S. 398, 403 (2006) (upholding “emergency aid" exception); U.S. v. Santana, 427 U.S. 38, 42 (1976) (upholding "hot pursuit" exception to prevent imminent destruction of evidence).

201 Requiring a student to provide administrators with his or her password, if one is needed to access the phone, raises other significant questions that are not addressed here.

202 Bryan A. Stillwagon, Bringing an End to Warrantless Cell Phone Searches, 45 GA. L. REV. 1165, 1204 (2008) (noting that, particularly in drug-related arrests, cell phones are useful but information that links a defendant to cell phone use is precisely the information that can be used to obtain a warrant). Requiring a warrant for a cell phone search is supported by the court's reasoning in Ohio v. Smith, 920 N.E.2d 949 (Ohio 2009), where the court based its decision, in part, on the fact that the defendant's cell phone itself posed no threat to the arresting officer and once the phone was in state custody, the immediate need to preserve and collect data was satisfied. 
Such a rule may raise questions about what type of harm would suffice. Are drug purchases rumored to be occurring on school grounds enough? Or must it be evidence of physical harm like information about a student who has a weapon and plans to use it in school? Each case must be evaluated according to the potential danger. School administrators must be able to distinguish between those searches that are necessary and those that are seeking more attenuated information. ${ }^{203}$ Even in emergency situations, searches should still be reasonably related in scope to the original justification for the search.

There is an obvious contradiction between, on the one hand limiting school administrators because they lack neutrality, and on the other hand entrusting them to distinguish the cases where imminent harm is at stake. However, this is precisely the same balancing act that police officers are entrusted to perform. The key lies in applying a standard that tips in favor of privacy protection rather than near-baseless intrusion.

A search of a cell phone is far more intrusive than the suspicionless drug-testing regimes authorized by the Supreme Court. In a random drug test, the student reveals nothing ancillary to the object of the test. They are simply found to be "clean" or not. However, a suspicionless search of a cell phone might reveal a broad range of information-medical, psychiatric, romantic, or otherwise deeply private-completely unrelated to the school's interest in monitoring compliance with school regulations.

\section{Proposed Guidelines for Public Schools}

At present, most schools in the United States have cell phone policies in place. $^{204}$ These policies typically prohibit any conduct involving a cell phone that results in students' distraction from learning.

203 The Supreme Court uses exactly this kind of measure in applying the public safety exception to the Miranda rule. New York v. Quarles, 467 U.S. 649, 658 (1984) ("But as we have pointed out, we believe that the exception which we recognize today lessens the necessity of that on-the-scene balancing process. The exception will not be difficult for police officers to apply because in each case it will be circumscribed by the exigency which justifies it. We think police officers can and will distinguish almost instinctively between questions necessary to secure their own safety or the safety of the public and questions designed solely to elicit testimonial evidence from a suspect.").

204 S. John Obringer \& Kent Coffey, Cell Phones in American High Schools: A National

Survey, 33 THE J. OF TECH'Y STUDIES 41 (2007), available at http://scholar.lib.vt.edu/ejournals/JOTS/v33/v33n1/obringer.pdf. 
Some schools allow students to have phones outside of class but prohibit their use inside class. Phones are usually confiscated as a sanction.

The rules as to when an administrator may search a phone should adhere to a strict standard that protects students' Fourth Amendment rights. In September 2011, the ACLU of California issued a report on privacy and student cell phones. The report suggests a school policy with a provision limiting searches. The provision states:

Notwithstanding any other school policies on searches in general, absent reasonable suspicion of wrongdoing with the device beyond merely possessing it or having it turned on or out in the open, school district employees may not search any personal telecommunications device without the express authorized consent of the student and the student's parent or legal guardian. ${ }^{205}$

This rule does not go far enough because it still allows administrators to use "reasonable suspicion" of wrongdoing ${ }^{206}$ as a guide. Instead, I propose that the policy should read:

Notwithstanding any other school policies on searches in general, school district employees may search a student's telecommunications device only if:

1) There is specific and credible evidence of imminent, specific harm, and

2) The scope of the search is narrowly tailored to address the imminent harm, or

3) School district employees have obtained express, authorized consent of the student and the student's parent or legal guardian, or a warrant.

No policy offers an airtight guarantee that school officials will correctly identify illicit activity at the expense of searching a student's phone. Nonetheless, a policy mandating that school officials articulate the particular evidentiary basis for searching a cell phone protects the privacy interests of students.

\section{CONCLUSiON}

New technologies challenge us to adapt legal principles to new circumstances and social norms. ${ }^{207}$ Developing appropriate constitutional

${ }^{205}$ ACLU of California, supra note 140.

$206 \mathrm{Id}$.

${ }^{207}$ Katherine M. O'Connor, OMG They Searched My Texts: Unraveling the Search and Seizure of Text Messages, 2010 U. ILL L. REV. 685, 715 (2010) (proposing that text 
protections with respect to teenagers is especially challenging because their own adolescent standards are ill-formed and appear designed to challenge notions of traditional reasonableness. ${ }^{208}$ Teenagers' behavior should not dictate the limits of their own zone of privacy for precisely the same reason that young people's rights are subjugated: because of their lack of maturity. It is a mistake to conclude that teenagers don't care about their privacy based on their choice to share intimate data about themselves with their friends via digital devices. ${ }^{209}$

Thus, adults should model appropriate standards of conduct and uphold our society's ideals and constitutional safeguards. ${ }^{210}$ Young people increasingly blur the boundaries between private and public, and it does them no good if adults enact policies that further blur those lines. If we want to teach our students to be more vigilant in maintaining their

messages be analogized to searches under the plain view doctrine and exigency exception); see also Leary, supra note 9; Matthew Orso, Cellular Phones, Warrantless Searches, and the New Frontier of Fourth Amendment Jurisprudence, 50 SANTA CLARA L. REV. 183 (2010); Amanda Yellon, The Fourth Amendment's New Frontier: Judicial Reasoning Applying the Fourth Amendment to Electronic Communications, 4 J. BUS. \& TECH. L. 411 (2009) (expectation of privacy analysis to emails).

208 Developments in science and brain imaging strongly suggest that the adolescent brain is developmentally incapable of making adult-like decisions and is, by virtue of its biological makeup, responsible in part for the poor decisions and risky behavior associated with teenagers. See Kevin W. Saunders, A Disconnect Between Law and Neuroscience: Modern Brain Science, Media Influences, and Juvenile Justice, 2005 UTAH L. REV. 695, 712 (2005) ("Children, including teenagers, may simply not be as capable as adults at inhibiting behavior. There is also evidence that this same lesser development of the same region of the brain makes it less likely that children will recognize the consequences of their acts.").

209 The United States Supreme Court has frequently acknowledged the relative immaturity of adolescents, or youths, under age eighteen. In Roper $v$. Simmons, the Court refused to allow the death penalty for children under eighteen. The opinion takes note of a youth's lack of maturity and "an underdeveloped sense of responsibility" qualities that often "result in impetuous and ill-considered actions and decisions." 543 U.S. 551, 570 (2005). See also Graham v. Florida, 130 S. Ct. 2011 (life without parole for juveniles accused of non-homicide offenses violates the Constitution).

210 Bd. of Educ. of Indep. Sch. Dist. No. 92 of Pottawatomie Cnty. v. Earls, 536 U.S. 822, 854 (2002) (Ginsberg, J., dissenting) ("When custodial duties are not ascendant, however, schools' tutelary obligations to their students require them to 'teach by example' by avoiding symbolic measures that diminish constitutional protections. That [schools] are educating the young for citizenship is reason for scrupulous protection of Constitutional freedoms of the individual, if we are not to strangle the free mind at its source and teach youth to discount important principles of our government as mere platitudes."); West Va. Bd. of Ed. v. Barnett, 319 U.S. 624, 637 (1943). 
privacy, we send the wrong message by breaching the line of privacy ourselves. ${ }^{211}$

School administrators are faced with tremendous social pressures and their need to maintain order should not be underestimated. Nevertheless, the primary mission of schools is to educate. This mission would be better served if adults in the school community modeled respect for student privacy. Requiring administrators to get a warrant to search the contents of a cell phone balances the legitimate safety concerns of school administrators with a student's right to privacy.

211 Not surprisingly, studies now show that older teens and young adults have a keener idea of keeping personal information private. A recent Pew study found that eighteen to twenty-nine-year olds have a greater concern about reigning in their private information than other age groups, vigilantly deleting posts that expose information or images they do not want to share. Mary Madden \& Aaron Smith, Pew Internet, Reputation Management and Social Media, available at http://pewinternet.org/ /media//Files/ Reports/2010/PIP_Reputation_Management_with_topline.pdf. 